Chapter 6

Micro-Gripping Methods and Applications 


\title{
A CRITICAL REVIEW OF RELEASING STRATEGIES IN MICROPARTS HANDLING
}

\author{
Gualtiero Fantoni, Marcello Porta \\ Department of Mechanical, Nuclear and Production Engineering, University of Pisa, Italy
}

\begin{abstract}
In the last ten years, various grasping principles and releasing techniques suitable for microassembly have been hypothesised and successfully tested. Since in microdomain adhesion forces overcome the gravity one, new grasping principles have been exploited to grasp microparts. Unfortunately, in microassembly the most critical phase is not to grasp a micropart, but to release it. Therefore, the development of releasing strategies plays a fundamental role in the entire assembly cycle. This paper proposes a scheme for classifying many releasing strategies developed in the microassembly field, provides a map of interesting grasping-releasing couples and analyses in detail one of the most reliable grasping principles (i.e. capillary gripper) and the related possible releasing strategies. Finally, a procedure for the selection of grasping and releasing strategies on the basis of the components to be handled and on the boundary conditions is provided.
\end{abstract}

Key words releasing, design for microassembly, grasping

\section{Introduction}

In the microassembly process, grippers are very important because they have to pick up microparts and release them with the correct orientation in the right place with high accuracy. Furthermore, they have to not damage or contaminate the microparts they handle. Many strategies have been developed for grasping microparts and the gripper configuration depends in general on the features of the object to be grasped and on the dominant forces at microscale [1]. Some microgrippers have been directly downscaled from the macro world while others, thanks to the very small dimensions and mass of handled microparts, take advantage of surface forces or other physical effects. A few authors have developed microgrippers changing systems [2] to handle many different microcomponents.

With the exception of few contactless grippers (e.g.: Bernoulli's, laser and sonodrote grippers), the main problem of the contact ones (exploiting friction, suction, jaw, surface forces etc.) concerns the releasing task. The gravity force, generally used in traditional assembly to release components, is often less relevant than adhesion forces in microdomain. Hence, components tend to remain stuck to the gripper, causing the need for the development of innovative releasing strategies.

Please use the following format when citing this chapter:

Fantoni, G., Porta, M., 2008, in IFIP International Federation for Information Processing, Volume 260, Micro-Assembly Technologies and Applications, eds. Ratchev, S., Koelemeijer, S., (Boston: Springer), pp. 223-234. 
Even if the releasing phase has been deeply discussed in [3, 4], novel strategies and approaches have been developed in the last few years. Therefore an up-to-date survey seems to be necessary. The methodology chosen in this paper for the study and the analysis of the releasing strategies in microassembly consists of the following steps:

- it starts from the collection of literature concerning the releasing phase;

- data are organised to highlight problems, advantages and opportunities of each releasing method;

- grasping strategies are coupled with the considered releasing methods;

- finally, each grasping principle has to be analysed to investigate possible releasing solutions: in this paper the capillary principle is considered as an example.

\section{Grasping and Releasing Strategies in Microdomain}

The main sources for the analysis of the releasing principles and strategies were papers, websites and technical documentations. This analysis allows the authors to cluster homogeneous papers and to organise them expanding the taxonomy from general principles to detail solutions.

The ontology proposed here splits the releasing strategies into two separate groups: passive releasing strategies (Table 1), where suitable gripper features or environment conditions make possible the reduction of adhesive forces between gripper and microparts; and active releasing strategies (Table 2), where parts can be released by means of additional actions. Passive releasing strategies exploit microgrippers features (in terms of shape, surface coatings and material) or environment conditions to reduce the force acting at the microscale, such as electrostatic, adhesion, van der Waals ones. On the contrary, the active releasing strategies make use of additional actions to allow the grasped object to be detached from the gripper. These additional actions can be (i) forces able to overcome the adhesive ones between gripper and object or (ii) means to reduce the contact area. With regard to additional forces, they can be supplied by external equipment or by suitable substrate (or substrate features) where the objects have to be released.

It is important to highlight that often releasing strategies make use of more than a single approach at the same time: in this case the authors tried to recognise the most significant releasing method. Furthermore obvious adjustments, such as for example a clean environment (dust is recognized to be a factor that modifies adhesion forces and friction [3]), are considered basic requirements for handling and do not appear in Table 1 and 2.

Tables 1 and 2 are organised as follows: each Releasing Principle is briefly described and a Scheme is provided. The Releasing Principle is defined as the physical principle which (i), decreasing the adhesive forces, makes gravity and/or other forces able to detach the part from the gripper or (ii), overcoming the adhesive 
forces, causes the releasing of the micropart. Table 1 (passive releasing strategies), differs from Table 2 (active releasing strategies) because it has not the columns Problems and Released components. Actually, while Table 1 contains general design rules applicable in cases of direct contact between the gripper and the micropart, conversely Table 2 also describes the Problems derived by the introduction of additional forces and provides a list of the Released components.

\begin{tabular}{|c|c|c|c|c|}
\hline Type & Principle & Scheme & Description & Force $\downarrow$ \\
\hline \multirow{7}{*}{$\frac{\vec{\Xi}}{\overparen{B}}$} & $\begin{array}{l}\text { Conductive } \\
\text { mate- } \\
\text { rial coatings } \\
\text {-Groninded } \\
\text { gripper }\end{array}$ & & $\begin{array}{l}\text { Conductive materials or coatings (which do } \\
\text { not form insulating oxides) reduce static } \\
\text { charges. Gromuded grippers prevent the } \\
\text { clarge storage }\{3,5\}\end{array}$ & electrostatic \\
\hline & $\begin{array}{l}\text { Low difference } \\
\text { of EV potential }\end{array}$ & & $\begin{array}{l}\text { Gripper and object made of materials with a } \\
\text { small potential difference reduce "contact } \\
\text { interaction" forces [5] }\end{array}$ & electrostatic \\
\hline & $\begin{array}{l}\text { Hydrophobic } \\
\text { coating }\end{array}$ & & $\begin{array}{l}\text { Hydrophobic coating reduces surface ten- } \\
\text { sion effects: it prevents the adsorption of } \\
\text { moisture [6] }\end{array}$ & $\begin{array}{l}\text { surface ten- } \\
\text { sion }\end{array}$ \\
\hline & $\begin{array}{l}\text { Low Hamaker } \\
\text { constant Coat- } \\
\text { ing }\end{array}$ & & $\begin{array}{l}\text { Low Hamaker constant coating reduces van } \\
\text { der Waals forces }\lceil 3\rceil\end{array}$ & van der Waals \\
\hline & Hard materials & & $\begin{array}{l}\text { Contact pressure causes deformations, in- } \\
\text { creasing the contact area between gripper } \\
\text { and object: grippers made of hard material } \\
\text { have to be preferred [5] }\end{array}$ & $\begin{array}{l}\text { van der } \\
\text { Waals, elec- } \\
\text { trostatic }\end{array}$ \\
\hline & $\begin{array}{l}\text { Rough surface } \\
\text { - Micro pira- } \\
\text { mids }\end{array}$ & & $\begin{array}{l}\text { The gripper roughness reduces the contact } \\
\text { area and sharp edges induce the self dis- } \\
\text { charge effect }[5,6]\end{array}$ & $\begin{array}{l}\text { van der } \\
\text { Waals; } \\
\text { electrostatic }\end{array}$ \\
\hline & $\begin{array}{l}\text { "Spherical" fin- } \\
\text { gers }\end{array}$ & & $\begin{array}{l}\text { Spherical fingers reduce the contact area in } \\
\text { comparison with planar ones }\lceil 5\rceil\end{array}$ & $\begin{array}{l}\text { van der } \\
\text { Waals; } \\
\text { surface } \\
\text { tension }\end{array}$ \\
\hline \multirow{5}{*}{ 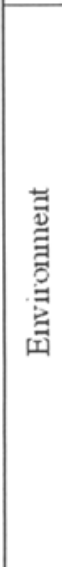 } & $\begin{array}{l}\text { Dry } \\
\text { atmosphere/ } \\
\text { Heating the } \\
\text { environment }\end{array}$ & & $\begin{array}{l}\text { A dry atmosphere reduces surface tension } \\
\text { effects (but increases the risk of } \\
\text { triboelectrification and the generation of } \\
\text { electrostatic force) }[3,5]\end{array}$ & $\begin{array}{l}\text { surface } \\
\text { tension }\end{array}$ \\
\hline & Vacuum & & $\begin{array}{l}\text { If no moisture affects the contact, there is no } \\
\text { liquid bridge and so surface tension is } \\
\text { reduced [5T (but risk of triboelectrification) }\end{array}$ & $\begin{array}{l}\text { surface } \\
\text { tension }\end{array}$ \\
\hline & $\begin{array}{l}\mathrm{No}_{2} \text { in the } \\
\text { environment }\end{array}$ & & $\begin{array}{l}\text { If there is no oxygen, native oxide can not } \\
\text { arise on the surface of gripper/handled } \\
\text { objects }[5]\end{array}$ & electrostatic \\
\hline & $\begin{array}{l}\text { In fluid } \\
\text { releasing }\end{array}$ & & $\begin{array}{l}\text { Assembly in fluid eliminates surface tension } \\
\text { effects and reduces electrostatic force }[5,7]\end{array}$ & $\begin{array}{l}\text { electrostatic; } \\
\text { surface } \\
\text { tension }\end{array}$ \\
\hline & Ionized air & & $\begin{array}{l}\text { Ionized air can neutralize free charges on the } \\
\text { sulfaces and so it reduces electrostatic force } \\
{[8]}\end{array}$ & electrostatic \\
\hline
\end{tabular}

Table 1. Passive releasing strategies 
Microparts Handling

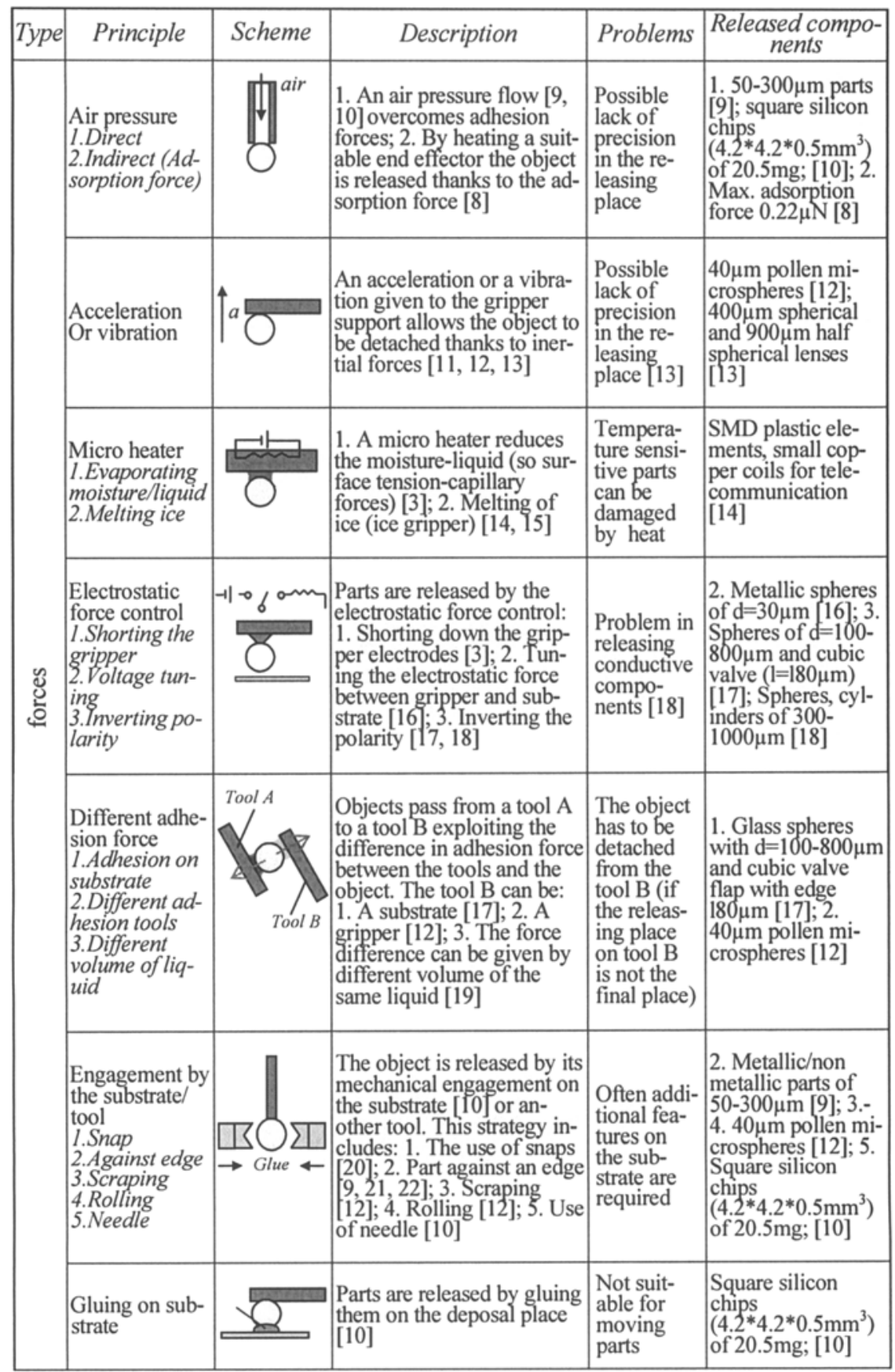




\begin{tabular}{|c|c|c|c|c|c|}
\hline \multirow{4}{*}{ 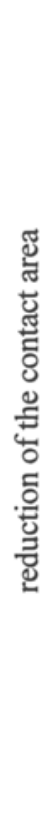 } & $\begin{array}{l}\text { 3D handling of } \\
\text { the gripper } \\
\text { l.Variation the } \\
\text { curvature } \\
\text { 2.Tilting } \\
\text { 3.Parallel mo- } \\
\text { tion }\end{array}$ & Add. too & $\begin{array}{l}\text { A decreasing of the contact } \\
\text { area through: 1. Varying } \\
\text { the gripper curvature from } \\
\text { a flat shape to a curved one } \\
{[23] ; 2 \text {. Tilting the gripper }} \\
{[24] ; 3 \text {. Parallel motion of }} \\
\text { the gripper respect to the } \\
\text { substrate [25] }\end{array}$ & $\begin{array}{l}\text { Complex } \\
\text { 3D han- } \\
\text { dling of the } \\
\text { gripper. } \\
\text { Many } \\
\text { DOF re- } \\
\text { quired. }\end{array}$ & $\begin{array}{l}\text { 1. Minimum object } \\
\text { weight } 98 \mathrm{mg}[23] \text {; } \\
\text { 2. Metallic spheres } \\
\text { of d }=20-30 \mu \mathrm{m} \\
{[24] ; 3.40 \mu \mathrm{m} \text { pol- }} \\
\text { len microspheres } \\
{[12]}\end{array}$ \\
\hline & Additional tool & & $\begin{array}{l}\text { An additional tool (with lit- } \\
\text { tle contact area with the ob- } \\
\text { ject) allows the object to be } \\
\text { first detached from the } \\
\text { gripper [24], then released } \\
\text { on the substrate by remov- } \\
\text { ing the tool }\end{array}$ & $\begin{array}{l}\text { Many de- } \\
\text { vices in a } \\
\text { small } \\
\text { space }\end{array}$ & $\begin{array}{l}\text { Metallic spheres } \\
\text { with diameter of } \\
20-30 \mu \mathrm{m}[24]\end{array}$ \\
\hline & $\begin{array}{l}\text { Roughness } \\
\text { change }\end{array}$ & & $\begin{array}{l}\text { The roughness change re- } \\
\text { duces adhesion forces al- } \\
\text { lowing the part to be re- } \\
\text { leased [3] }\end{array}$ & $\begin{array}{l}\text { Difficulties } \\
\text { in realiza- } \\
\text { tion }\end{array}$ & \\
\hline & Electrowetting & 吕 & $\begin{array}{l}\text { The modification of the } \\
\text { liquid drop by an electro- } \\
\text { static field reduces the con- } \\
\text { tact area [11] }\end{array}$ & $\begin{array}{l}\text { Difficulties } \\
\text { in menis- } \\
\text { cus control }\end{array}$ & \\
\hline
\end{tabular}

Table 2. Active releasing strategies

The classification schemes proposed in Tables 1 and 2 have to be considered as necessary steps for the development of rules for the selection of the most suitable couples of grasping-releasing principle. Actually, in order to make grippers able to pick and place microparts in a reliable way, often a grasping approach has to be coupled, from the design phase, with one or more releasing strategies. Table 3 updates the works presented in $[26,27]$ and has been created to map the grasping principles and the possible releasing strategies adopted and/or suggested in literature. The grasping methods are adapted from the classification of grasping principles carried out by [1], while releasing methods come from the classification reported in Tables 1 and 2. In comparison with [1], the item "Surfaces forces (general)" has been introduced in grasping methods to include authors that generally refer to adhesive forces as grasping forces [24]. 
Microparts Handling

\begin{tabular}{|c|c|c|c|c|c|c|c|c|c|c|}
\hline & \multicolumn{7}{|c|}{ GRASPING PRINCIPLES } \\
\hline & & & & 导 & 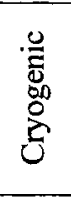 & 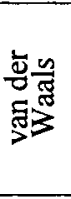 & 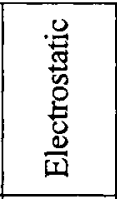 & 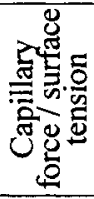 & 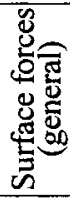 & 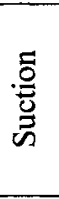 \\
\hline \multirow{21}{*}{ 至 } & \multirow{10}{*}{ 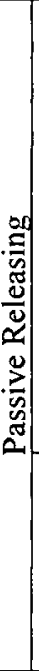 } & \multirow{10}{*}{ 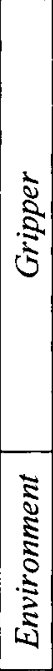 } & $\begin{array}{l}\text { Conductive mate- } \\
\text { rial/coatings }\end{array}$ & {$[5]$} & & [3] & [3] & & {$[3]$} & \\
\hline & & & Low difference of EV & [5] & & & & & & \\
\hline & & & Hydrophobic coating & & & & & $\begin{array}{l}{[11,} \\
28]\end{array}$ & [4] & \\
\hline & & & Hard materials & {$[5]$} & & & & & & \\
\hline & & & Rough surface & $\begin{array}{l}{[5]} \\
{[6]}\end{array}$ & & [3] & & & {$[3]$} & \\
\hline & & & "Spherical" fingers & {$[5]$} & & & & & & \\
\hline & & & Dry atmosphere & [5] & & & & & [3] & \\
\hline & & & Vacuum & & & & & & [3] & \\
\hline & & & In fluid releasing & & & & & & {$[7]$} & \\
\hline & & & Ionized air & & & & {$[3]$} & & & \\
\hline & \multirow{8}{*}{\multicolumn{2}{|c|}{ 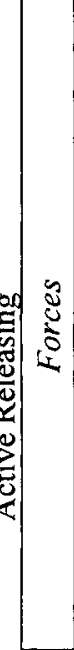 }} & Air pressure & & & & & {$[10]$} & & [9] \\
\hline & & & Acceleration or vibration & & & & {$[13,18]$} & $\begin{array}{l}{[11,} \\
12]\end{array}$ & [3] & \\
\hline & & & Micro heater & & $\begin{array}{l}{[14,} \\
15]\end{array}$ & & & & {$[3]$} & [8] \\
\hline & & & $\begin{array}{l}\text { Electrostatic force con- } \\
\text { trol }\end{array}$ & & & & $\begin{array}{c}17,18 \\
29]\end{array}$ & & [3] & \\
\hline & & & Different adhesion force & & & & {$[17]$} & $\begin{array}{l}{[12} \\
19]\end{array}$ & & \\
\hline & & & $\begin{array}{l}\text { Engagement by the sub- } \\
\text { strate }\end{array}$ & & & & [22] & $\begin{array}{l}{[10,} \\
12]\end{array}$ & & [9] \\
\hline & & & Gluing on substrate & & & & & {$[10]$} & & [30] \\
\hline & & & $\begin{array}{l}\text { 3D handling of the grip- } \\
\text { per }\end{array}$ & & & $\begin{array}{l}{[25,} \\
31]\end{array}$ & [24] & $\begin{array}{l}{[11,} \\
12]\end{array}$ & & \\
\hline & \multirow{3}{*}{\multicolumn{2}{|c|}{ 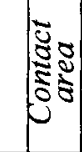 }} & Additional tool & & & & {$[24]$} & [11] & & \\
\hline & & & Roughness contact area & [3] & & & & & & \\
\hline & & & Electrowetting & & & & & [11] & & \\
\hline
\end{tabular}

Table 3. Releasing strategies available for grasping strategies 


\section{Releasing Strategies for Capillary Gripper}

Each grasping principle and all the possible releasing methods in Table 3 can be analysed further. Hereinafter the case of capillary gripper has been used as an example. As demonstrated by the numerous papers in literature [19, 21, 23], the capillary gripper is one of the most reliable. The advantages of capillary grippers are [21] the ability to grasp:

- small components (the available capillary force is few $\mathrm{mN}$ );

- components with only one upper free surface;

- components with a small available grasping area;

- any kind of component in terms of material and shape;

- fragile components because the meniscus acts as a "bumper".

Moreover there is a favourable downscaling law (the force is proportional to the linear dimension). Finally, the capillary gripper is compliant and exerts a self centering effect due to surface tension.

Most of the releasing strategies in Tables 1 and 2 can be used for releasing objects grasped by capillary grippers. Unfortunately, the releasing phase is difficult even if numerous systems have been tested. Table 4 focuses on releasing approaches developed in literature for capillary grippers.

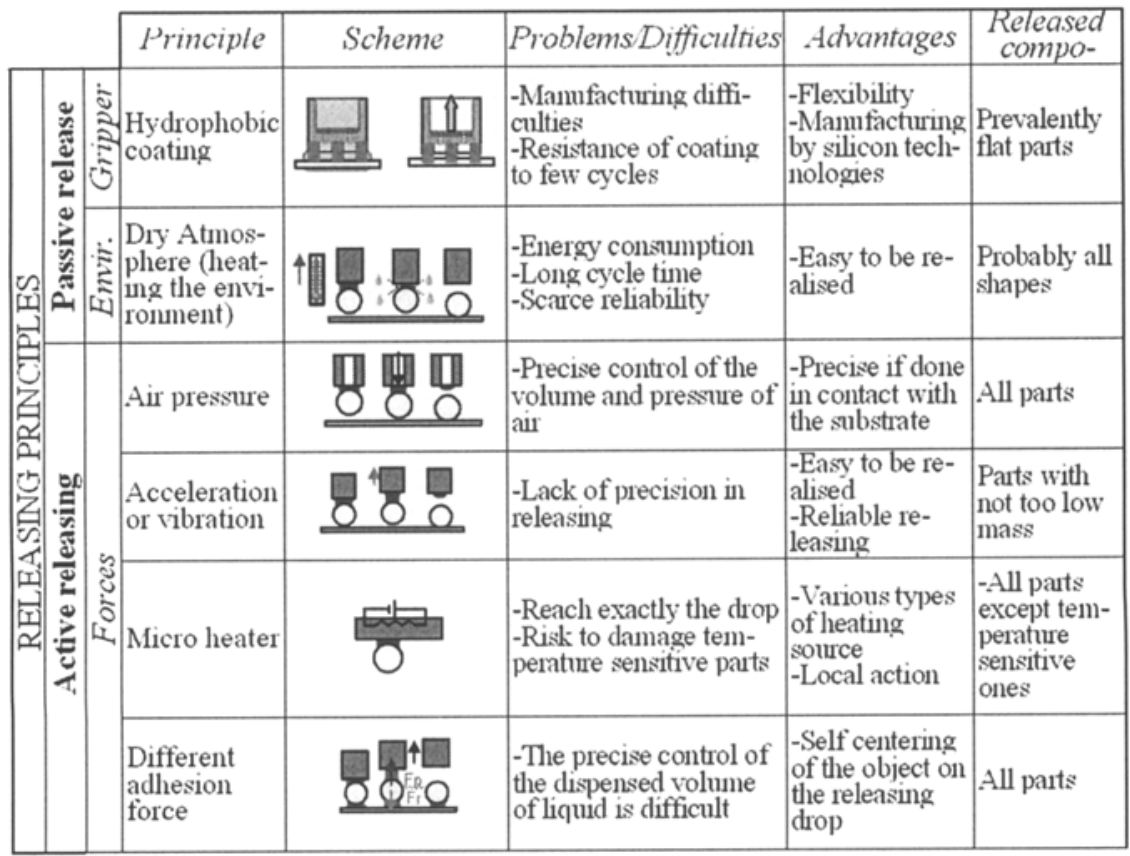




\begin{tabular}{|c|c|c|c|c|c|}
\hline & $\begin{array}{l}\text { Engagement } \\
\text { by the sub- } \\
\text { strate/tool }\end{array}$ & Ш & $\begin{array}{l}\text {-Often not precise } \\
\text {-Releasing from other } \\
\text { tool } \\
\text {-Structured substrate } \\
\text {-Damages on the part }\end{array}$ & $\begin{array}{l}\text {-Reliable re- } \\
\text { leasing }\end{array}$ & $\begin{array}{l}\text { It can de- } \\
\text { pend on } \\
\text { substrate } \\
\text { features }\end{array}$ \\
\hline & $\begin{array}{l}\text { Gluing on } \\
\text { substrate }\end{array}$ & & $\begin{array}{l}\text {-Releasing precision } \\
\text { depending on the glue } \\
\text {-Glue volume control } \\
\text {-Glue curing }\end{array}$ & $\begin{array}{l}\text {-Self centering } \\
\text { on } \\
\text { the glue drop }\end{array}$ & All parts \\
\hline & $\begin{array}{l}\text { 3D handling } \\
\text { of the grip- } \\
\text { per }\end{array}$ & & $\begin{array}{l}\text {-Difficulties in the sur- } \\
\text { face curvature control } \\
\text {-Difficult to reach } \\
\text { small radii of curvature }\end{array}$ & $\begin{array}{l}\text {-Flexibility } \\
\text {-Many actua- } \\
\text { tion strategies } \\
\text { are available }\end{array}$ & $\begin{array}{l}\text { Prevalently } \\
\text { flat parts }\end{array}$ \\
\hline \multirow{3}{*}{$\mid \begin{array}{c}5 \\
5 \\
\vdots \\
\vdots \\
\vdots \\
\vdots \\
\vdots \\
\vdots \\
\vdots \\
\vdots\end{array}$} & $\begin{array}{l}\text { Additional } \\
\text { tool }\end{array}$ & & $\begin{array}{l}\text {-Difficult to reach the } \\
\text { part without wetting } \\
\text { the tool } \\
\text {-Damages on the part }\end{array}$ & -Precision & $\begin{array}{l}\text { Probably } \\
\text { all; better if } \\
\text { flat pauts }\end{array}$ \\
\hline & $\begin{array}{l}\text { Roughness } \\
\text { change } \\
\text { (increase } \\
\text { getp) }\end{array}$ & & $\begin{array}{l}\text {-Manufacturing diffi- } \\
\text { culties } \\
\text {-Need for hydrophobic } \\
\text { needles }\end{array}$ & -Flexibility & $\begin{array}{l}\text { Probably } \\
\text { all: better if } \\
\text { flat parts }\end{array}$ \\
\hline & $\begin{array}{l}\text { Electrowet- } \\
\text { ting }\end{array}$ & & $\begin{array}{l}\text {-Difficulties in menis- } \\
\text { cus curvature control } \\
\text {-Charges induced both } \\
\text { in liquid and compo- } \\
\text { nent }\end{array}$ & $\begin{array}{l}\text {-Direct control } \\
\text { of the liquid } \\
\text { meniscus } \\
\text { (force) }\end{array}$ & $\begin{array}{l}\text { Prevalently } \\
\text { spherical } \\
\text { parts }\end{array}$ \\
\hline
\end{tabular}

Table 4. Releasing strategies related to capillary grasping

\section{Selection of Suitable Grasping-Releasing Strategy}

As reported in [1], the selection of the suitable microgrip principle depends both on part characteristics in terms of physical and functional features (such as material, shape, mass, function, etc.) and on the boundary conditions (i.e. environment and assembly tasks). Once the grip principle has been chosen, it is necessary to verify which are the releasing strategies suitable to be coupled with the selected grasping approach (Table 3). If no releasing strategy shown in Table 1 and 2 makes possible the releasing of the components, a different microgrip principle has to be selected. Hence, only a correct selection of both the grasping and the releasing strategy allows a reliable design of the gripper. Actually, for each grasping method various releasing approaches can be used but, as shown in Table 4 for capillary grippers, every releasing strategy presents some advantages and drawbacks and is suitable to release components with particular features.

The procedure, proposed for the selection of the grasping-releasing strategy, is shown in Figure 1. 


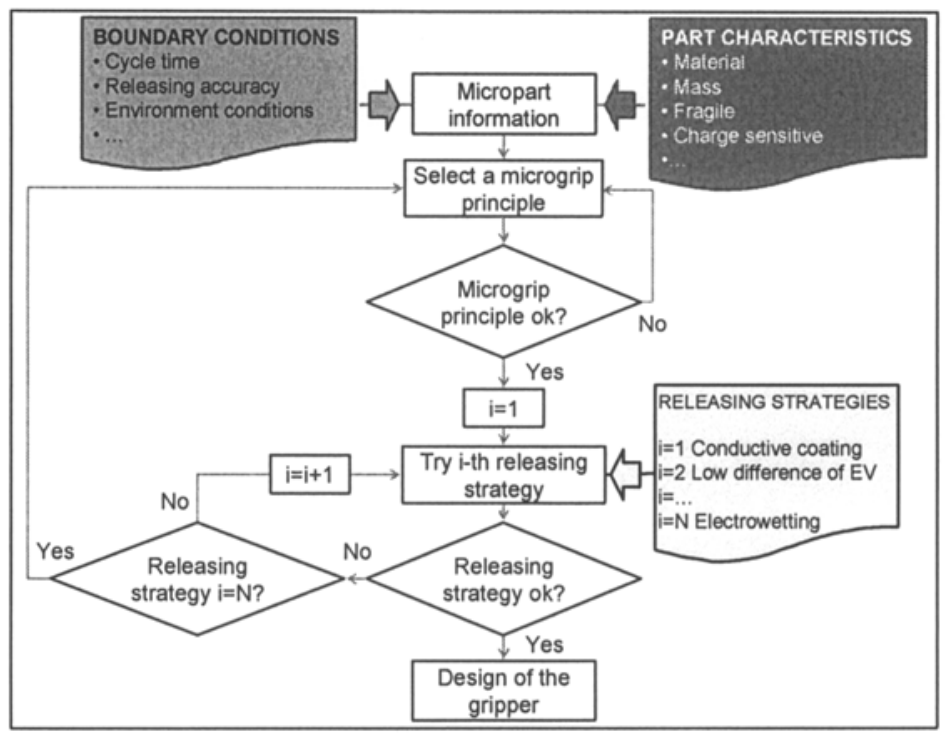

Figure 1. Conceptual procedure for the grasping-releasing selection

With regard to part characteristics, geometrical parameters are one of the first drivers in the selection. For example (see Table 4), a flat component could be grasped and released with capillary grippers owning hydrophilic and hydrophobic coating but probably the same gripper is not able to handle spheres and cylinders. Moreover, it is necessary to know the component properties and functions, i.e. if components are fragile, porous, dielectric, conductive, magnetic, diamagnetic, charge and water sensitive, etc. and/or if their surface is polished or must have optical characteristics. Actually, fragile parts can be damaged by mechanical grippers but also by a high stress releasing such as an engagement on the substrate or the use of an additional tool. For instance, charge sensitive SMD are altered by electrostatic grippers or electrowetting releasing. Optical lenses can be stained by the remaining traces left by liquid grippers. Similar damages can occur when these parts are released with glue or mechanical tool such as needles.

With regard to the boundary conditions, information about the initial status of the microparts is also necessary to choose the best grasping tool. Therefore different choices can be done if the parts are randomly positioned or correctly fed, if they are separated, regularly spaced (ordered) or they present difficulties in feeding (e.g. they stick, nest, tangle, or they are slippery, flexible, squiggle etc.). For example, an adhesive or an electrostatic gripper is not able to pick only a sphere from a group of some spheres in contact. Conversely if the parts are sufficiently spaced both princi- 
ples can be successfully exploited. Also the requirements of the final positioning (2D, 3D, fine, coarse, etc.) determine the choice of the gripper or conversely prevent the use of some grasping principles. For example, a compliant adhesive gripper cannot be used for a forced peg-in-hole operation, while it could be particularly suitable for pick-and-place operation of delicate micro parts. Finally, the environment plays a fundamental role because it can allow or prevent the use of some grasping principles: even in a clean environment the small amount of dust can dramatically reduce the performance of a gripper (such as an electrostatic one) both in the grasping and in the releasing phase.

\section{Conclusion and Future Development}

A critical survey of the releasing strategies in microassembly has been performed. These strategies are organised in a novel classification scheme to allow a structured selection of the suitable methods for releasing a grasped microcomponent. Then, a matching of the possible releasing approaches related to each grasping principle has been developed and it should help the designer with a simple decision map. Furthermore, a deeper analysis of a particular microgripper (i.e. the capillary one) has been performed: the releasing strategies, allowed in this case, are compared in terms of advantages, drawbacks and handled components. In order to help the designer in the right choice of both grasping and releasing principle a step-bystep procedure has been finally proposed.

Future works concern the development of Design for Microassembly rules by extending this work to other grasping principles and assembly operations as for example microfeeding, microsorting, microinserting, microforcing and microgluing.

\section{Acknowledgements}

This research has been partially supported by the Italian Ministry of University and Research (MIUR) within the project 'Development of innovative technologies for the assembly of hybrid microproducts'. The authors thank Prof. M. Santochi for his continuous help and suggestions.

\section{References}

[1] Tichem, M., Lang, D., Karpuschewski, B., 2003, A classification scheme for quantitative analysis of micro-grip principles, Proc. of the $1^{\text {st }}$ Int. Precision Assembly Seminar (IPAS'2003), 17-19 March, Bad Hofgastein, Austria.

[2] Clevy, C., Hubert, A., Agnus, J., Chaillet, N., 2005, A micromanipulation cell including a tool changer, Journal of Micromechanical and Microengineering vol.15/10, pp. 292-301. 
[3] Arai, F., Andou, D., Fukuda, T., Nonoda, Y., Oota T., 1995, Micro Manipulation Based on Micro Physics -Strategy Based on Attractive Force Reduction and Stress Measurement-, Proc. of IEEE/RSJ Conf. on Robots and Intelligent Systems 2, pp. 236-241.

[4] Van Brussel, H., Peirs, J., Reynaerts, D., Delchambre, A., Reinhart, G., Roth, N., Weck, M., Zussman, E., 2000, Assembly of Microsystems, Annals of the CIRP, vol. 49/2.

[5] Fearing, R.S., 1995, Survey of sticking effects for micro parts handling, IEEE/RSJ International Workshop on Intelligent Robots \& Systems (IROS), Pittsburgh.

[6] Arai, F., Andou, D., Nonoda, Y., Fukuda, T., Iwata, H., Itoigawa, K., 1996, Micro end effector with micro pyramids and integrated piezoresistive force sensor, Proc. of the IEEE/RSJ Int. Conf. on Intelligent Robots and Systems.

[7] Gauthier, M., Lopez-Walle, B., Clevy, C., 2005, Comparison between microobjects manipulations in dry and liquid mediums, Proc. of CIRA'05, Espoo, Finland.

[8] Arai F., Fukuda, T., 1997, Adhesion-type Micro Endeffector for Micromanipulation, Proc. of the IEEE Int. Conf. on Robotics and Automation (ICRA'97), pp. 1472-1477.

[9] Zesch, W., Brunner, M., Weber, A., 1997, Vacuum tool for handling microobjects with a NanoRobot, Proc. of the IEEE Int. Conf. on Robotics and Automation (ICRA'97), pp. 761-776.

[10] Bark, C., Binneboese, T., 1998, Gripping with low viscosity fluid, IEEE Int. workshop on MEMS, pp. 301-305.

[11] Lambert, P., 2005, PhD Thesis, Faculté des sciences appliquées, Université Libre de Bruxelles.

[12] Driesen, W., Varidel, T., Régnier, S., Breguet, J.-M., 2004, Micromanipulation by adhesion with two collaborating mobile micro robots, $4^{\text {th }}$ Int. Workshop on Microfactories.

[13] Monkman, G.J., 2003, Electroadhesive Microgrippers, Assembly Automation vol. 24/1, MCB University Press.

[14] Kochan, A., 1997, European project develops "ice" gripper for micro-sized components, Assembly Automation, vol. 17/2, pp. 114-115.

[15] Lang, D., Kurniawan, I., Tichem, M., Karpuschewski, B., 2005, First investigations on force mechanisms in liquid solidification micro-gripping, In $\mathrm{C}$ Mascle (Ed.), ISATP 2005; the $6^{\text {th }}$ IEEE Int. symposium on assembly and task planning, pp. 1-6.

[16] Saito, S., Himeno, H., Takahashi, K., Onzawa, T., 2002, Electrostatic detachment of a micro-object from a probe by applied voltage, Int. Conf. on Intelligent Robots and System, vol. 2, pp. 1790-1795.

[17] Hesselbach, J., Büttgenbach, S., Wrege, J., Bütefisch, S., Graf, C., 2001, Centering electrostatic microgripper and magazines for microassembly tasks, Microrobotics and Microassembly 3, Proc. of SPIE, vol. 4568, Newton, USA.

[18] Fantoni, G., Biganzoli, F., 2004, Design of a novel electrostatic gripper, International Journal for Manufacturing Science and Production, 6/4, pp. 163-179.

[19] Obata, K.J., Motokado, T., Saito, S., Takahashi, K., 2004, A scheme for micro-manipulation based on capillary force, Journal of Fluid Mechanics, vol. 498, pp. 113-121. 
[20] Prasad, R., Böhringer, K.-F., MacDonald, N. C., 1995, Design, fabrication, and characterization of single crystal silicon latching snap fasteners for micro assembly, in ASME Int. Mech. Eng. Congr. Expo., pp. 917-923.

[21] Lambert, P., 2006, Design of a capillary gripper for a submillimetric application, Proc. of the $3^{\text {rd }}$ Int. Precision Assembly Seminar (IPAS'2006), Bad Hofgastein, Austria, 19-22 February.

[22] Enikov, E.T., Lazarov, K.V., 2001, Optically transparent gripper for microassembly, SPIE, vol. 4568, pp. 40-49.

[23] Pagano, C., Ferraris, E., Malosio, M., Fassi, I., 2003, Micro-handling of parts in presence of adhesive forces, CIRP Seminar on Micro and Nano Technology 2003, Copenhagen, November 13-14, pp. 81-84.

[24] Koyano, K., Sato, T., 1996, Micro object handling system with concentrated visual fields and new handling skills, Proc. of the IEEE Int. Conference on Robotics and Automation, pp. 2541-2548.

[25] Miyazaki, H., Sato, T., 1996, Pick and place shape forming of three dimensional micro structures from fine particles, Proc. of the IEEE Int. Conf. on Robotics and Automation, ICRA'96, pp. 2535-2540.

[26] Santochi, M., Fantoni, G., Fassi, I., 2005, Assembly of microproducts: state of the art and new solutions, Proc.of the AMST'05, Udine June 8-9, pp. 99-115.

[27] Porta, M., 2007, PhD Thesis, Department of Mechanical Nuclear and Production Engineering, University of Pisa.

[28] Fantoni, G., 2005, PhD Thesis, Department of Mechanical Nuclear and Production Engineering, University of Pisa.

[29] Nakao, M., Tsuchiya, K., Matsumoto, K., Hatamura, Y., 2001, Micro Handling with Rotational Needle-type Tools Under Real Time Observation, Annals of the CIRP, vol. 50/1.

[30] Ansel, Y., Schmitz, F., Kunz, S., Gruber, H.P., Popovic, G., 2003, Development of tools for handling and assembling micro components, Journal of Micromechanics and Microengineering, pp. 430-437.

[31] Lambert P., Delchambre A., 2003, Forces Acting on Microparts: towards a numerical approach for gripper design and manipulation strategies in micro assembly, Proc. of the $1^{\text {st }}$ Int. Precision Assembly Seminar (IPAS'2003), 1719 March, Bad Hofgastein, Austria. 